\title{
Penyajian Data Pelanggan pada Lima Area PT. Telekomunikasi Indonesia, Tbk. Kandatel Pekalongan Menggunakan Google Earth
}

\author{
Much Aziz Muslim', Atikah Ari Pramesti ${ }^{2}$ \\ ${ }^{1,2}$ Program Studi Teknik Informatika, FMIPA, Universitas Negeri Semarang \\ Email: ${ }^{1} a 212 m u s l i m @ y a h o o . c o m,{ }^{2}$ atikaharipramesti@gmail.com
}

\begin{abstract}
Abstrak
Prosedur sistem penyajian data pelanggan di PT. Telekomunikasi Indonesia, Tbk. Kandatel Pekalongan khususnya bidang Divisi Business Services masih menggunakan cara manual, hanya menggunakan media Micorsoft Excel. Dalam hal ini peneliti ingin menerapkannya dalam bentuk aplikasi Google Earth untuk membuat penyajian data pelanggan, karena Google Earth dapat memetakan bumi dari superimposisi gambar yang dikumpulkan dari pemetaan satelit, fotografi udara dan globe GIS tiga dimensi sehingga akan menghasilkan data yang akurat. Penyajian data dengan menggunakan Google Earth dilakukan dengan memanfaatkan bahasa markup HTML. Dengan cara ini, Divisi Business Service akan menjadi lebih mudah ketika menyajikan data-data para pelanggan Telkom yang mencakup lima area yaitu Batang, Pekalongan, Pemalang, Tegal dan Brebes.
\end{abstract}

Kata Kunci: PT. Telekomunikasi Indonesia, Tbk., Penyajian data, Google earth

\section{PENDAHULUAN}

PT. Telekomunikasi Indonesia, Tbk. Kandatel Pekalongan adalah salah satu kantor daerah yang terletak di Pekalongan. Perusahaan tersebut memiliki area pelanggan yang cukup luas meliputi, area Batang, Pekalongan, Pemalang, Tegal dan Brebes. Pada setiap jaringan yang terpasang di pelanggan memungkinkan akan terjadinya kesalahan. Dikarenakan adanya masalah tersebut maka solusi yang tepat adalah memonitor data pelanggan PT. Telekomunikasi Indonesia, Tbk. Kandatel Pekalongan untuk mempermudah ketika pencarian data pelanggan dan mengecek nomor identitas layanannya.

Dari hasil observasi menunjukkan bahwa dalam penyajian data pelanggan masih sangat minim, hanya menggunakan Microsoft Excel kemudian mengunggahnya kedalam Google Drive. Selain itu pihak Telkom khususnya bidang Divisi Business Services $(D B S)$ yang bekerja dibidang marketing masih mengalami kesulitan dalam mencari data pelanggan seperti halnya identitas layanan pelanggan, alamat rumah ataupun instansi, contact-person, dan sebagainya yang terlalu banyak. Bahkan sangat tidak memungkinkan jika seorang pegawai harus menghafal semua identitas pelanggan yang jumlahnya mencakup lima area di Telkom Kandatel Pekalongan. 
Pelanggan adalah semua orang yang menuntut organisasi untuk memenuhi standar kualitas tertentu, dan karena itu memberikan pengaruh pada kinerja organisasi $[1,2]$. Oleh karena itu menurut Pelanggan adalah: (1) orang yang tidak bergantung pada perusahaan, tetapi sebaliknya; (2) orang yang membawa organisasi untuk mengikuti keinginannya; (3) orang yang teramat penting yang harus dipuaskan [1]. Karena itu, tidak ada seorangpun yang pernah menang beradu argumentasi dengan pelanggan [1].

Microsoft Excel sudah dikenal sebagai program spreadsheet yang paling dikenal saat ini, ini karena keandalanya dalam melakukan pengolahan data, terutama data-data yang berkenaan dalam bentuk angka (kuantitatif) [3]. Program aplikasi pada Microsoft Office yang digunakan dalam pengolahan angka (Aritmatika). Program ini sering digunakan oleh para akuntan untuk menuliskan atau mencatat pengeluaran dan pemasukan di dalam perusahaan atau suatu lembaga maupun instansi-instansi kecil.

Google Earth merupakan sebuah program globe virtual yang sebenarnya disebut Earth Viewer dan dibuat oleh Keyhole, Inc.. Program ini memetakan bumi dari superimposisi gambar yang dikumpulkan dari pemetaan satelit, fotografi udara dan globe GIS (Sistem Informasi Geografis) tiga dimensi. Sistem infromasi geografis (GIS) adalah aplikasi desain komputer secara digital yang digunakan untuk mengambil, menyimpan, memanipulasi, menganalisa, dan menganalisa informasi geografi [4].

HTML adalah sebuah bahasa untuk menampilkan halaman sebuah website. HTML merupakan singkatan dari Hyper Text Markup Language. HTML bukan termasuk dalam bahasa pemrograman, tetapi HTML adalah "markup language", "markup language" ini merupakan sekumpulan "tag". "Tag" inilah yang digunakan untuk menampilkan halaman website dalam tampilan tertentu.

Dengan adanya penyajian data pelanggan yang terstruktur dan praktis, mampu membantu pihak PT. Telekomunikasi Indonesia, Tbk. Kandatel Pekalongan khususnya dibidang Divisi Business Services (DBS) dalam mengelola data-data dan menampilkannya dalam bentuk tabel yang dikemas dengan tag HTML melalui Google Earth.

\section{METODOLOGI}

Dalam perancangan aplikasi surat masuk dan keluar pada PT. Angkasa Pura 1 Semarang mempunyai beberapa tahapan diadopsi sesuai dengan siklus hidup sistem informasi [5] sebagai berikut. (a) Tahap pengambilan data awal, (b) Tahap analisis kebutuhan system, (c) Tahap Pembuatan desain dan (d) Tahap pembuatan program. Hasil rancangan dan pembuatan program diuraikan dan dijelaskan secara deskriptif naratif.

Untuk mengecek keberhasilan dari sistem, dilakukan tahap pengujian. Tahap ini adalah dengan melakukan uji mengenai kesalahan-kesalahan yang ada dalam pembuatan program. Kesalahan-kesalahan dalam pengujian adalah sebagai berikut. (a) Kesalahan Bahasa, merupakan kesalahan dalam penulisan kode program yang kurang tepat dengan kriteria dan bahasa pemrograman dari program yang digunakan; 
(b) Kesalahan Proses, merupakan kesalahan yang muncul ketika program dijalankan. Kesalahan ini mengakibatkan program berhenti melakukan proses sebelum seharusnya program tersebut berhenti karena program tidak menemukan objek yang dijalankan dan (c) Kesalahan Logika, merupakan kesalahan yang cukup sulit ditemukan karena kesalahan ini tidak tampak jelas saat program dijalankan. Program tetap bisa berjalan dengan normal dan menampilkan hasil, akan tetapi hasil yang ditampilkan tidak sesuai dengan yang diharapkan [5].

\section{HASIL DAN PEMBAHASAN}

\subsection{Cara Penyajian Data Pelanggan}

Penyajian data pelanggan pada PT. Telekomunikasi Indonesia, Kandatel Pekalongan dilakukan dengan dua cara yaitu pertama, penyajian data pelanggan secara manual menggunakan Microsoft Excel dan yang kedua, penyajian laporan hasil olahan data para pelanggan dari Microsoft Excel ke Google Earth.

\subsubsection{Penyajian Data Pelanggan Secara Manual Menggunakan Microsoft Excel}

Dalam penyajian data pelanggan secara manual, langkah pertama yang harus dilakukan yaitu menyiapkan data-data pelanggan dari nama instansi, status (negeri atau swasta), alamat, kecamatan, kode pos dan contact person. Dalam menyiapkan data-data pelanggan digunakan bantuan search engine Google. Setelah data-data pelanggan lengkap maka data tersebut ditata secara berurutan dengan Microsoft Excel. Penyajian data secara manual dapat dilihat pada Gambar 1.

\begin{tabular}{|c|c|c|c|c|c|c|}
\hline \multicolumn{3}{|c|}{ KABUPATEN PEKALONGAN } & \multirow[b]{2}{*}{ Alamat } & \multirow[b]{2}{*}{ Kecamatan } & \multirow[b]{2}{*}{ Kode Pos } & \multirow[b]{2}{*}{$\mathrm{CP}$} \\
\hline No & \begin{tabular}{|c|} 
Nama Sekolah \\
\end{tabular} & Status & & & & \\
\hline 1 & SMK NURUL UMMAH PANINGGARAN & Swasta & Jalan Raya Paninggaran, Sawangan/ pkl & Peninggaran & 51164 & $(0285) 521010$ \\
\hline 2 & SMK 1 LEBAKBARANG & Negeri & J. Raya Lebakbarang & LEBAKBARANG & 51183 & $(0285) 4475401$ \\
\hline 3 & SMK MUHAMMADIYAH TALUN & Swasta & ds. Donowangun, Donowangun & Tahun & 51192 & \\
\hline 4 & SMK MA'ARIF NU DORO & Swasta & J. Raya Doro Jolotigo & Doro & 51191 & 02854484165 \\
\hline 5 & SMK MUHAMMADIYAHDORO & Swasta & Kalimojosari & Doro & 51192 & $(085642514131$ \\
\hline 6 & SMK MUHAMMADIYAH KARANGANYAR & Swasta & IL. Raya Karanganyar-Kajen KM 3 & KARANGANYAR & 51182 & $(0285) 381496$ \\
\hline 7 & SMK DIPONEGORO KARANGANYAR & Swasta & Jl. Raya Karanganyar KM 1,5 Kayugeritan & Karanganyar & 51182 & $(0285) 7932223$ \\
\hline 8 & SMK ISLAM HASBULLAH & Swasta & JL. KEMPONG RAYA PODODADI, PODODADI, & Karanganyar & 51183 & 081326985948 \\
\hline 9 & SMK MUHAMMADIYAH KAJEN & Swasta & Jl. Pahlawan - Kajen Kab. Pekalongan, Gejlig & Kajen & 51161 & $(0285) 381464$ \\
\hline
\end{tabular}

Gambar 1. Penyajian data secara manual menggunakan microsoft excel

Penyajian data pelanggan dengan cara tersebut diterapkan tidak hanya pada area Pekalongan, namun juga pada keempat area PT. Telekomunikasi Indonesia, Tbk. Kandatel Pekalongan lainnya yaitu Batang, Pemalang, Tegal dan Brebes. Cara tersebut dilakukan secara berulang hingga data benar-benar lengkap.

\subsection{Penyajian Data Pelanggan dari Hasil Olahan Microsoft Excel ke Google Earth}


Penyajian data yang dilakukan secara manual dengan menggunakan Microsoft Excel sebenarnya sudah cukup lengkap untuk dijadikan sebuah penyajian data, namun dalam menyajikan data pelanggan alangkah baiknya jika dilengkapi dengan denah dari lokasi pelanggan sehingga menghasilkan data yang lebih akurat. Maka dari itu diterapkanlah hasil olahan data pelanggan di PT. Telkom Kandatel Pekalongan dari Microsot Excel ke Google Earth.

\subsubsection{Penandaan Lokasi}

Sejak kemunculan GIS, dan perkembangan manfaat pentingnya Sistem Informasi Geografis (GIS) didalam pengolahan data, alamat juga mempunyai arti penting sebagai identifikasi pemilihan yang universal [6].

Dalam melakukan penyajian data pelanggan di PT. Telekomunikasi Indonesia, Tbk. Kandatel Pekalongan mengunakan Google Earth dilakukan penandaan pada setiap lokasi pelanggan sehingga menghasilkan data yang lengkap dan akurat. Langkahlangkah dalam melakukan penandaan lokasi menggunakan Google Earth dijelaskan sebagai berikut. (a) Dalam penandaan lokasi lima area Telkom Kandatel Pekalongan langkah pertama yang harus dilakukan yaitu menyiapkan semua data-data pelanggan yang telah ditata dengan Microsoft Excel, (b) Setelah penyiapan data pelanggan selesai maka langkah selanjutnya yaitu pendataan titik koordinat garis lintang dan garis bujur dengan menggunakan Google Earth. Penyajian pendataan titik kooridnat ini langsung menggunakan Google Earth. Data yang disajikan lebih ringkas dari data pertama yaitu hanya penyajian nama instansi, alamat, latitude, longtitude dan contact person.

Cara mencari titik koordinat garis lintang dan bujur pada Google Earth sebagai berikut.

Pertama, Buka tampilan Google Earth. Pada sisi kiri atas terdapat toolbar Search. Tuliskan nama lokasi yang akan dicari titik koordinatnya kemudian klik tombol "Telusuri". Sebagai contoh dicari titik koordinat dari SMAN 2 Pemalang. Tampilan Search pada Google Earth dapat dilihat pada Gambar 2.

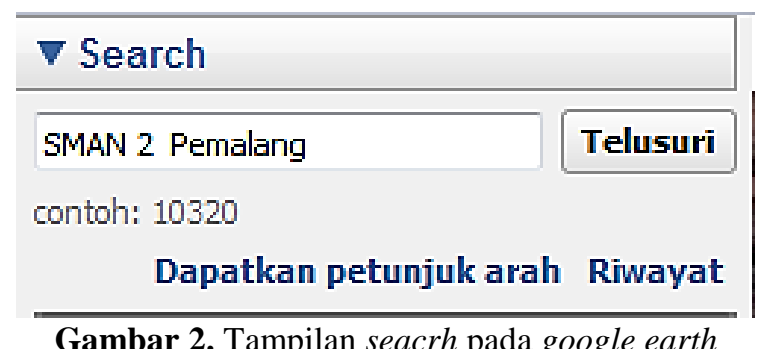

Gambar 2. Tampilan seacrh pada google earth

Setelah klik telusuri maka otomatis Google Earth akan mencari dimana letak lokasi tersebut. Karena alamat yang dimasukan sudah sangat jelas maka Google Earth hanya memberikan satu pilihan yang sesuai dengan kriteria nama lokasi yang dicari dan begitu pula dengan sebaliknya. Tampilan hasil pencarian dapat dilihat pada Gambar 3 . 


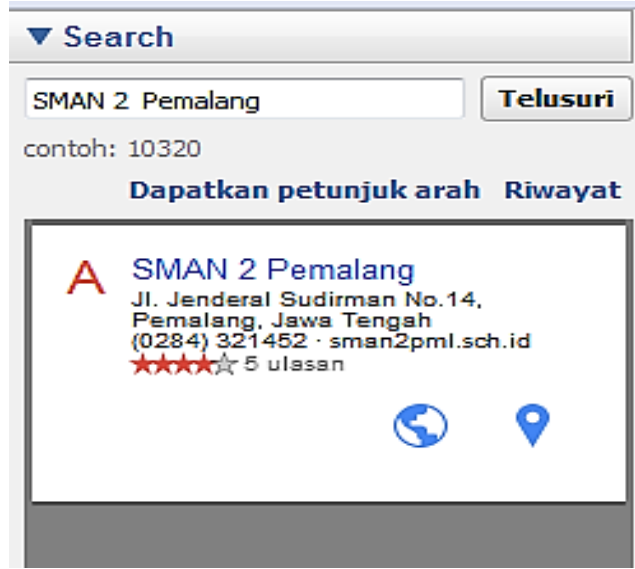

Gambar 3. Tampilan hasil pencarian pada google earth

Setelah ditemukan penunjuk arah dari lokasi SMAN 2 Pemalang, kemudian pada penujuk arah tersebut kita tambahkan tanda letak. Klik "Tanda Letak" yang berwarna kuning pada toolbar atas. Tampilan menu toolbar dapat dilihat pada Gambar 4.

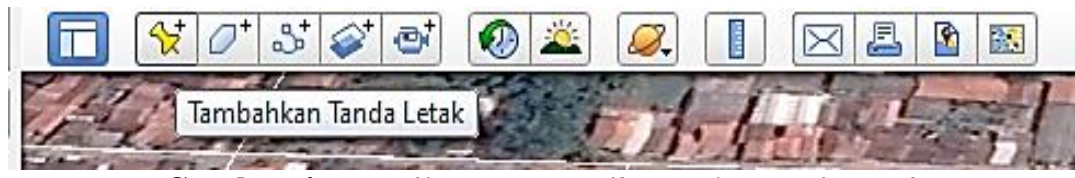

Gambar 4. Tampilan menu toolbar pada google earth

Kemudian letakan tanda tepat pada penujuk arah sehingga akan menghasilkan titik koordinat yang sempurna. Pada penanda letak akan ditampilkan nama serta garis lintang dan garis bujur. SMAN2 Pemalang terletak pada garis lintang 653'30.00'S dan garis bujur $109^{\circ} 24^{\prime} 18.09^{\prime \prime} T$. Garis lintang dan garis bujur dapat dilihat pada Gambar 5.

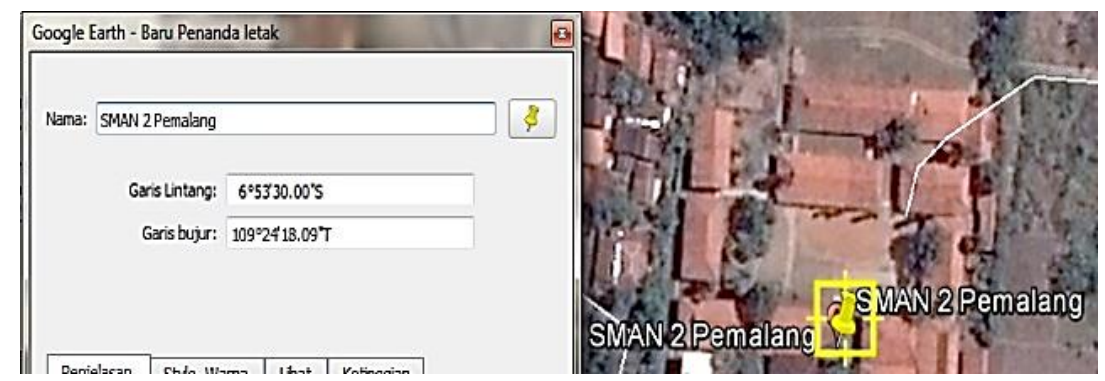

Gambar 5. Garis lintang dan garis bujur

Penandaan lokasi lima daerah Telkom Kandatel Pekalongan adalah sebagai berikut. Lakukan langkah pertama hingga langkah ketiga secara berutan. Kemudian pada langkah ketiga dilanjutkan dengan pembuatan tampilan untuk memperindah dengan menggunakan tampilan tabel agar lebih praktis. Pembuatan tampilan dilakukan dalam 
"Penandaan Letak" pada kolom "Penjelasan". Dalam pembuatan tampilan tabel menggunakan bahasa pemrograman HTML. Untuk source code nya dapat dilihat pada Gambar 6.

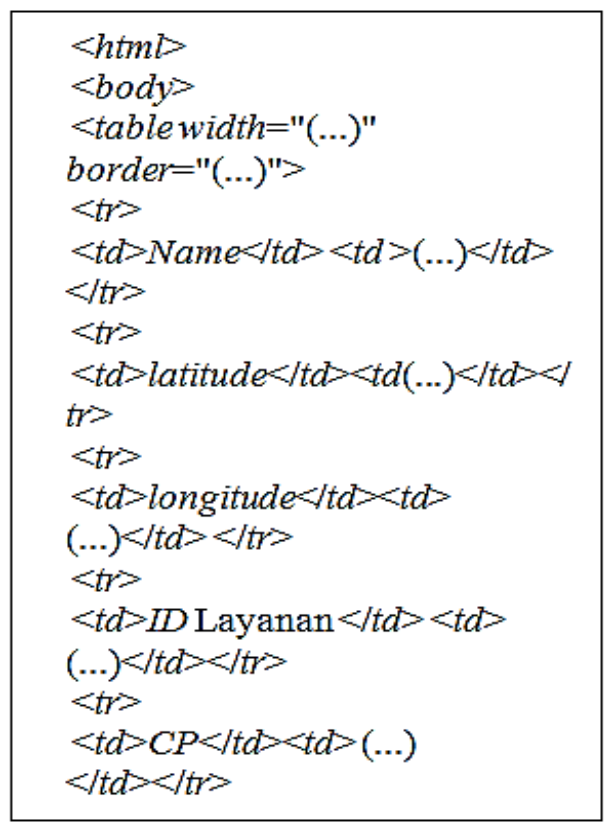

Gambar 6. Source code tampilan tabel

Kemudian isikan nama instansi diikuti dengan latitude dan longtitude yang sudah tertera dalam penanda letak. Data $I D$ (identitas) Layanan dan $C P$ (contact person) dapat dilihat dari data-data pada Microsoft Excel. Tampilan penanda letak dapat diperlihatkan pada Gambar 7.

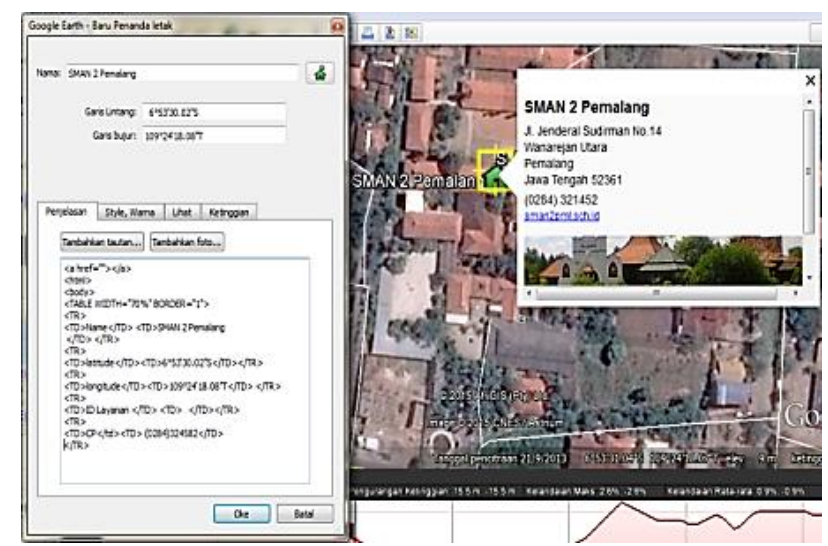

Gambar 7. Tampilan penanda letak pada google earth 
Terkahir klik Oke maka akan keluar tampilan info dari SMAN 2 Pemalang. Tampilan penyajian data pada SMAN 2 Pemalang dapat dilihat pada Gambar 8.

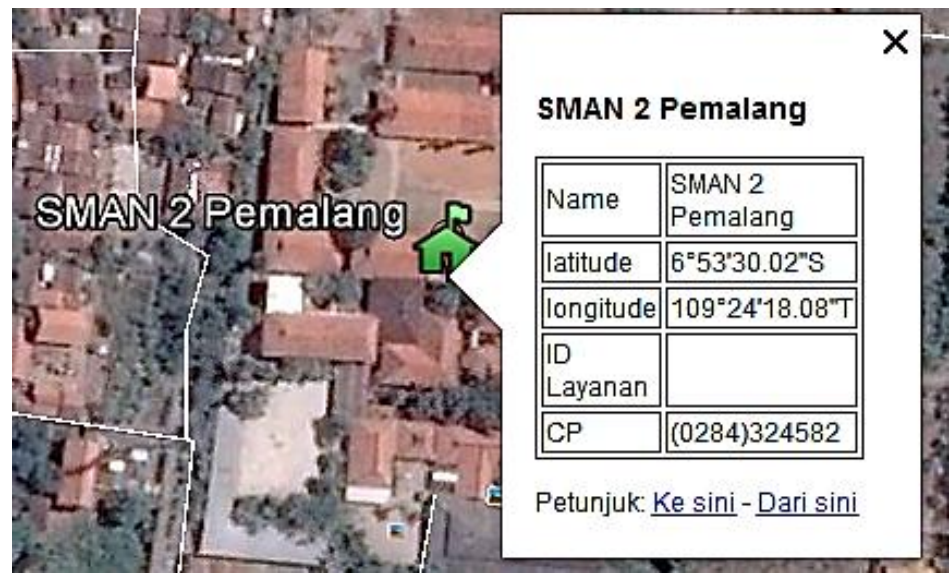

Gambar 8. Penyajian data SMAN 2 Pemalang

Lakukan langah-langkah tersebut secara berulang pada lima area PT. Telekomunikasi Indonesia, Kandatel Pekalongan sehingga menghasilkan data yang akurat pada Google Earth. Penyajian data yang dilakukan dengan menggunakan Google Earth tentunya akan membantu Divisi Business Service dalam penyajian data para pelanggan yang tersebar di lima area PT. Telekomunikasi Indonesia, Kandatel Pekalongan.

\section{SIMPULAN}

Cara menyajikan data pelanggan yang mencakup lima area PT. Telekomunikasi Indonesia, Tbk. Kandatel Pekalongan yaitu dilakukan dengan dua cara; (1) Penyajian data secara manual menggunakan Microsoft Excel yaitu kumpulan data yang diperoleh, kemudian disusun menurut kategori-kategori. Meliputi nama sekolah, atau instansi, serta alamat yang dilengkapi dengan kecamatan, kemudian nomor id pelanggan, dan contact person. (2) Penyajian data dari hasil olahan Microsoft Excel ke Google Earth yaitu data-data yang sudah diolah menggunakan Microsoft Excel kemudian diterapkan kedalam Google Earth, dan data yang ditampilkan lebih akurat dibandingkan data yang dibuat dengan Microsoft Excel. Cara menyajikan data para pelanggan PT. Telekomunikasi Indonesia, Tbk. Kandatel Pekalongan dari hasil olahan Microsoft Excel ke Google Earth yaitu dengan penandaan letak setiap lokasi pelanggan diikuti dengan titik koordinat lokasi tersebut. Penyajian data pelanggan pada Google Earth dikemas dengan bahasa Hyper Text Markup Language (HTML) sehingga menjadi lebih menarik dalam memberikan sebuah penyajian data pelanggan pada PT. Telekomunikasi Indonesia, Tbk. Kandatel Pekalongan. Karena dalam Google Earth terdapat bangunan-bangunan tiga dimensi sehingga membuat pengguna lebih tertarik dalam melihat informasi data pelanggan. 


\section{REFERENSI}

[1] Nasution, M.N. 2005. Manajemen Mutu Terpadu (Total Quality Management). Ghalia Indonesia, Jakarta.

[2] Muslim, M.A. 2005. Aplikasi Penentuan Rute Terbaik Berbasis Sistem Informasi Geografis. Jurnal Ilmiah Teknologi Informasi. Vol. 10(2): 76-83.

[3] Tampake, S.H. 2007. Penggunaan AJAX pada Pengembangan Aplikasi Web. Jurnal Teknologi Informasi-Aiti. Vol. 4(1): 1-100.

[4] Muslim, M.A. Aplikasi Penentuan Alamat Berbasis GIS (Address Information System). Jurnal Teknologi Informasi. Vol. 10(1): 19-24.

[5] William, Brian K. Using information technology: a practical introduction to computers \& communications: Complete version. McGraw -Hill, New York.

[6] Tofik, Moch. 2008. Membuat Aplikasi Akuntansi Dengan Microsoft Excel 2007. Mediakita, Jakarta. 